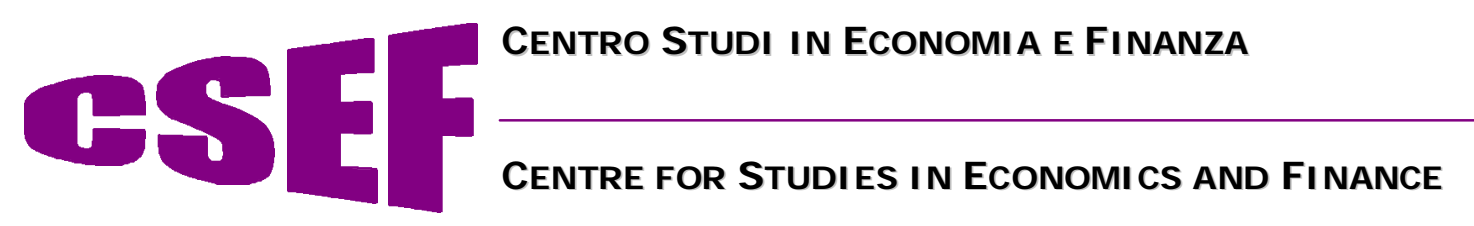

WORKING PAPER no. 11

\title{
Borrowing Constraints, Portfolio Choice, and Precautionary Motives: Theoretical Predictions and Empirical Complications
}

Michael Haliassos and Christis Hassapis

November 1998

We are grateful to Carol Bertaut, Chris Carroll, Tullio Jappelli, Marco Pagano, Nick Souleles, Guglielmo Weber, and Joachim Winter for very helpful discussions. We have benefited from comments by participants at the Savings and Pensions TMR conference (Tilburg), the Economics and Finance seminar series at CSEF (Italy), and the Capital Markets conference (Cyprus). Mary Karatsi-Christou provided excellent research assistance. We thank the European Union and the Research Committee of the University of Cyprus for financial support. Part of this research was completed while the authors were visiting the Center for Studies in Economics and Finance at the University of Salerno (Italy), which provided an excellent research environment.

DIPARTIMENTO DI SCIENZE ECONOMICHE - UNIVERSITÀ DEGLI STUDI DI SALERNO

Via Ponte Don Melillo - 84084 FISC IANO (SA)

Tel. 089-96 3167/3168 - Fax 089-96 3169 - e-mail: csef@ xcom.it 


\title{
WORKING PAPER no. 11
}

\author{
Borrowing Constraints, Portfolio Choice, and Precautionary \\ Motives: Theoretical Predictions and Empirical Complications
}

\author{
Michael Haliassos** and Christis Hassapis***
}

\begin{abstract}
This paper studies effects of two classes of borrowing constraints, collateral- and income-based, on wealth accumulation, portfolio behavior and on precautionary motives. We examine the sensitivity of solutions to tightness of constraints, education level, and preference parameters. The models are calibrated using the 1992 Survey of Consumer Finances. The idea that constrained households engage in less borrowing and less holding of risky assets than desired is borne out for income-based constraints but not necessarily for constraints where assets also serve as collateral. The commonly used nonnegativity constraint on wealth turns out to be a very special case among collateral constraints: not only is constrained consumption equal to income but precautionary wealth holding is zero. Incomebased constraints reverse the sign of precautionary effects on holdings of risky assets, and so do relatively tight collateral constraints. The latter reverse the sign of precautionary effects on borrowing, as well. Precautionary effects on wealth holding and on borrowing are smaller when income-based constraints are binding, though not necessarily so for collateral constraints. Results suggest that inclusion of constrained households in a sample of unconstrained ones is quite likely when using standard wealth-level cutoffs for sample splitting, and that it tends to bias empirically observed precautionary effects on wealth downwards. Estimated precautionary effects on risky assets and on borrowing may even be biased towards zero. These findings may help explain the failure of recent empirical studies to uncover sizeable precautionary effects on wealth and on portfolio composition.
\end{abstract}

Keywords: Precautionary saving, borrowing constraints, household portfolios.

JEL classification codes: G11, E21

Mailing Address: Department of Economics - University of Cyprus P.O. Box 537 - CY 1678 Nicosia - Cyprus

email addresses: Haliassos: haliassos@aya.yale.edu (Corresponding author) Hassapis: christis@ucy.ac.cy

\footnotetext{
* University of Cyprus and IMOP (Athens)

** University of Cyprus
} 


\section{Table of contents}

1. Introduction

2. Borrowing Constraints

2.1 Income-based Constraints

2.2 Asset-based or Collateral Constraints

3. The Underlying Saving-Portfolio Model

3.1 Analytics

3.2 Calibration

4. Effects of Borrowing Constraints on Saving and on Portfolio Choice

4.1 Income-based Constraints

4.2 Collateral Constraints

5. Precautionary Motives

5.1 Effects of Introducing Income-based Constraints

5.2 Effects of Introducing Collateral Constraints

6. Implications for Empirical Testing

6.1 Estimating Precautionary Effects

6.2 Sample-splitting Criteria

7. Concluding Remarks

References

Tables

Figures 


\section{Introduction}

Modern analysis of consumption-saving behavior has long been dominated by the Life Cycle-Permanent Income Hypothesis, recently augmented to incorporate income risk and precautionary motives. ${ }^{1}$ Its standard form rules out liquidity constraints and typically abstracts from portfolio choice. The two modeling choices reinforce each other: the assumed absence of quantity restrictions on asset holdings and of an interest-rate wedge removes two reasons for consideration of portfolio choice. Their combination underplays the potential importance of financial market conditions, monetary policy, and credit tightness for consumption and welfare.

Econometric and calibration studies have shown the potentially rich implications of both factors. Deaton (1991) showed through computation that borrowing constraints (nonnegativity of the single asset) can have substantial effects on saving in the presence of nondiversifiable labor income risk. Estimation often shows excess sensitivity of consumption to changes in income, and liquidity constraints are thought of as strong, though not the only, candidates for explaining it. ${ }^{2}$ Recent empirical literature has shown the explicit relevance of credit variables for consumption in financially developed countries. ${ }^{3}$ Unlike constraints with constant borrowing limits, endogenous (and potentially time-varying) constraints introduce a role for credit conditions in influencing consumption and welfare. These include limits that depend on income and collateralizable assets and are potentially different across households, countries, and time periods. They also nest nonnegativity constraints on wealth or debt, allowing examination of their special nature.

Studies that incorporate portfolio choice, often combined with background labor income risk, find important interactions between saving and portfolio decisions even without liquidity constraints, identify portfolio and return puzzles that challenge 
some premises of standard models, and show nontrivial precautionary portfolio effects. ${ }^{4}$ Yet, empirical studies have yielded mixed results regarding the existence and quantitative importance of precautionary influences on saving and portfolio choice (see Guiso, Jappelli, and Terlizzesse, 1992, 1996; Hochguertel, 1998).

Papers studying effects of borrowing constraints on portfolio choice under labor income risk include Constantinides et al. (1998), Gakidis (1998), Hochguertel (1998), Koo (1991), Marcet and Singleton (1991), and Paxson (1990). Constantinides et al. argue that borrowing constraints can contribute to explaining both the high equity premium and the low riskless rate, since they prevent the young from borrowing to invest in stocks. Gakidis examines a version of the buffer stock hypothesis extended to incorporate portfolio choice. Hochguertel and Koo investigate the effects of nonnegativity constraints on wealth, effectively requiring $100 \%$ collateral for borrowing and implying equality of consumption with income. The borrowing limits considered by Marcet and Singleton are a specific fraction of labor income. Paxson derives some analytic results for a version of collateral constraints.

This paper studies influences of income- and collateral-based borrowing constraints on wealth accumulation, portfolio behavior, and precautionary motives. Robustness of the findings is checked by computing solutions for three education categories and associated stochastic processes for labor income, and by varying preference parameters. Calibration is based on the 1992 Survey of Consumer Finances. An important innovation is that the paper compares effects of various degrees of constraint tightness for two classes of (potentially) time-varying constraints, nesting standard specifications of nonnegativity constraints on wealth and on debt. Extensive comparisons are made possible by use of a small-scale model. In addition to uncovering new effects and assessing the robustness of others, these 
comparisons suggest a possible explanation for the failure of empirical studies to date to uncover sizeable precautionary effects using household-level data.

The idea that constrained households engage in less borrowing and less holding of risky assets than desired is borne out for income-based constraints but not necessarily for constraints where assets also serve as collateral. The commonly used nonnegativity constraint on wealth turns out to be a very special case among collateral constraints: not only is constrained consumption equal to income but precautionary wealth holding is zero. Income-based constraints reverse the sign of precautionary effects on holdings of risky assets, and so do relatively tight collateral constraints. The latter reverse the sign of precautionary effects on borrowing, as well. Precautionary effects on wealth holding and on borrowing are smaller when income-based constraints are binding, though not necessarily so for collateral constraints. Results suggest that inclusion of constrained households in a sample of unconstrained ones is quite likely when using standard wealth-level cutoffs for sample splitting, and that it tends to bias empirically observed precautionary effects on wealth downwards. Estimated precautionary effects on risky assets and on borrowing may even be biased towards zero.

Section 2 describes the two types of constraints. Section 3 presents the model and calibration procedure. Section 4 discusses effects of each type of constraint on wealth accumulation and portfolio choice. Section 5 derives precautionary effects for the two types of constraints. Section 6 draws implications for the estimated size of precautionary effects when borrowing constraints are not fully accounted for, and then discusses criteria for splitting samples into constrained and unconstrained households. Section 7 offers concluding remarks. 


\section{Borrowing Constraints}

\subsection{Income-based Constraints}

The first class of constraints we consider involves a borrowing ceiling tied to income. This is motivated by the argument that ability to repay is related to earning capacity, and that current earnings are a good proxy for future earnings potential. ${ }^{5}$ Formally, borrowing is not allowed to exceed a proportion (or multiple) $k$ of income:

$$
-B_{t} \leq k Y_{t}, \quad k>0 .
$$

Notice that the borrowing limit is not conditioned on other portfolio components, and that it is not manipulable by the household, as it relates to exogenous labor income. ${ }^{6}$

If the constraint is binding in period $t$, then $B_{t}+k Y_{t}=0$, and net worth is $W_{t}=S_{t}-k Y_{t}$. When net worth exceeds this amount, the constraint is not binding. Thus, constrained net worth is a function of the tightness parameter $k$, and of holdings $S_{t}$ that are endogenous and themselves a function of constraint tightness.

\subsection{Asset-based or Collateral Constraints}

Perhaps the most widely researched quantity constraint on borrowing is the nonnegativity constraint on net wealth, $W_{t} \geq 0$. This constraint allows borrowing up to exactly the amount of collateral provided by assets that are included in computation of financial net worth. Nothing else can be used as collateral, including human wealth. In a single-asset model, this amounts to the restriction that borrowing cannot take place at all (unless debt liabilities are fully backed by positive holdings of the same asset as the one issued in order to borrow). Regardless of the asset menu, constrained consumption must always equal current income.

A natural generalization in a two-asset model is to consider constraints of the form

$$
-B_{t} \leq b S_{t}, \quad b \geq 0
$$


where $B$ stands for net holdings of bonds (and $-B$ stands for net borrowing) at the riskless interest rate ${ }^{7} S$ is the other asset entering computation of net worth; and $b$ is an institutional parameter describing collateral requirements, i.e., the tightness of the constraint. ${ }^{8}$ The familiar constraint $W_{t} \geq 0$ then becomes a special case for $b=1$. The practice of ruling out short sales of both bonds and stocks is encompassed by the case $b=0$ (or equivalently $k=0$ ). The constraint preventing short sales of stock is never binding in any of our experiments. Cases where net borrowing is restricted to be a fraction (or even a multiple) $l$ of net worth, i.e.

$$
-B_{t} \leq l \cdot W_{t}, \quad l \geq 0,
$$

are also encompassed. This constraint can be shown to be equivalent to

$$
-B_{t} \leq \frac{l}{l+1} S_{t}
$$

which is subsumed in constraint (2) above for $b<1$.

An important feature of collateral constraints is that the ceiling on borrowing is manipulable through portfolio selection, since it is related to holdings of other assets. This has interesting and sometimes surprising implications, as will be seen below. When constraints are binding in period $t$, net worth is equal to $(1-b) S_{t}$. Otherwise, net worth exceeds this product. Thus, constrained wealth is equal to zero only for $b=1$, but it is otherwise endogenous and depends on the tightness of constraints and on all other factors determining asset holdings $S_{t}$, including preferences and stochastic income processes. This point will be important in some of what follows.

Which assets are subsumed under $S$ depends, of course, on the model at hand. It is not unusual for collateral assets, financial or real, to bear some risk. In what follows, we focus on consumer loans and on risky financial collateral that offers an expected return premium over the loan interest rate. In two-asset models with bonds and stocks, 
loan collateral is provided by any positive bond holdings and by holdings of stock. ${ }^{9}$ Risky asset holdings, then, play a dual role. They are held both because of the return premium and because they relax the borrowing limit.

\section{The Underlying Saving-Portfolio Model}

\subsection{Analytics}

Each household is assumed to maximize expected utility subject to uncertainty regarding labor income and asset returns. We consider three education categories facing different stochastic processes for labor income. Results are derived for idiosyncratic income shocks uncorrelated with returns. Households have an economic life of three twenty-year periods, and make decisions at the end of each period. Utility in the first and second periods displays constant relative risk aversion (CRRA):

$$
U_{t}=U\left(c_{t}\right)=\frac{c^{1-\gamma}-1}{1-\gamma}, \quad t=1,2 \quad 0<\gamma \neq 1
$$

where $\gamma$ is the degree of relative risk aversion. Utility in the last (retirement) period incorporates concern about the size of bequest, as follows:

$$
U_{3}=U\left(c_{3}, G\right)=(1-\lambda) \frac{c_{3}^{1-\gamma}-1}{1-\gamma}+\lambda \frac{G^{1-\gamma}-1}{1-\gamma}, \quad 0<\gamma \neq 1
$$

where $G$ is the size of bequests. The size of $\lambda$ controls the intensity of the bequest motive with $\lambda=0$ corresponding to no such motive. The household solves:

$$
\begin{gathered}
\operatorname{Max} E_{1} \sum_{t=1}^{3} \beta^{t-1} U_{t}, \quad 0<\beta<1 \\
\text { s.t. } \quad c_{l}=A_{0}+Y_{1}-N_{1} \frac{P S_{1}}{P_{l}}-\frac{B_{1}}{P_{l}}
\end{gathered}
$$




$$
\begin{gathered}
c_{2}=Y_{2}+\left(N_{1} d_{2}+\frac{B_{1} I_{2}}{P_{2}}\right)\left(1-t_{b}\right)+\left(N_{1}-N_{2}\right) \frac{P S_{2}}{P_{2}}+\frac{B_{1}-B_{2}}{P_{2}} \\
c_{3}=Y_{3}+N_{2}\left[\frac{P S_{3}}{P_{3}}+d_{3}\left(1-t_{b}\right)\right]+\frac{B_{2}\left[1+I_{3}\left(1-t_{b}\right)\right]}{P_{3}}-G \\
c_{t} \geq 0 \forall t .
\end{gathered}
$$

where $A_{0}$ is initial (inherited) wealth, $P S_{t}$ is the nominal stock price in period $t, N$ the number of stocks, $B$ the nominal amount in bonds, $d$ real dividends per share, $I$ the nominal rate of interest on the riskless asset, $P$ the price of the good, and $t_{b}$ the tax rate on interest and dividend income.

At the end of the first period, the household decides how to allocate labor income between current consumption and saving in either riskless or risky assets offering an expected return premium. These are held over the second period, when it is subject to stochastic income shocks. Thus, the household is faced with career uncertainty, the size of which depends on its education level, as described below. At the end of the second period, just before retirement, the household adjusts its wealth holding and portfolio mix to hold during retirement. Retirement income is assumed to be nonrandom, but dependent on the household's education, as also in Hubbard, Skinner and Zeldes $(1994,1995)$. By the end of that period, the household decides how to divide up current after-tax resources (i.e., retirement income, stock accumulation, dividend payments, any bond holdings minus accumulated debt and associated interest payments) between final consumption and bequests. The model incorporates taxation on income, interest, and dividends, but not on capital gains. ${ }^{10}$ Interest and dividend tax rates are higher for college graduates than for those of lower education.

\subsection{Calibration}

Calibration of cumulative stock returns is based on a binomial model of annual stock returns that matches the first two moments of the long-run empirical return distribution estimated by Mehra and Prescott (1985) [see also Haliassos (1994)]. Stock 
returns can take a high or low value equal to the expected value plus or minus (respectively) the standard deviation of 20-year holding returns. Consistent with the historical findings of Schwert (1990), expected dividend yields are calibrated to about half the expected total pre-tax return on equity. The twenty-year riskless rate is compounded from the Mehra-Prescott mean annual riskless rate. Under no correlation between income and stock returns and no retirement income risk, the model has four second-period and eight third-period states. Its small scale allows us to solve it a large number of times, exploring alternative parameter configurations.

In calibrating income, we follow the approach introduced in Bertaut and Haliassos (1997). We distinguish between households with (i) less that high-school education (LTHS), (ii) high-school education (HS), and (iii) at least a college degree (COL). In models without income risk, the household is guaranteed the average population income for the relevant age-education cell, computed from the 1992 Survey of Consumer Finances (SCF). Incomes under certainty are equal to expected incomes under career uncertainty and both are equal to average population incomes computed from the data. ${ }^{11}$ Income risk is introduced in the form of lognormally distributed, multiplicative stochastic shocks to annual incomes, which follow processes estimated by Hubbard, Skinner, and Zeldes (1994):

$$
\begin{gathered}
u_{L T H S, t}=0.955 u_{L T H S, t-1}+e_{L T H S, t}, e_{L T H S, t}-i . i . d . N(0,0.033), v_{L T H S, t} N(0,0.04) \\
u_{H S, t}=0.946 u_{H S, t-1}+e_{H S, t}, e_{H S, t} \text { i.i.d.N(0,0.025), } v_{H S, t} N(0,0.021) \\
u_{C O L, t}=0.955 u_{C O L, t-1}+e_{C O L, t}, e_{C O L, t} \text { i.i.d.N(0,0.016), } v_{C O L, t} N(0,0.014)
\end{gathered}
$$

In our end-of-period model, first-period income is known by the time the first decision is made, and third-period income is assumed nonstochastic. The relevant income measure is the present value of incomes over twenty-year periods. Present values 
for both periods are set equal to the population averages for the corresponding ageeducation cell. Second-period income is stochastic and its analytical moments are not readily computed from the assumptions on annual income shocks. We therefore stochastically simulate annual incomes (for ages 40 to 60 ) and generate 10,000 present value realizations for each education level. These take into account serial correlation of annual income shocks, and they are used to compute expected present values and their standard deviations. The "high" and "low" values for each education level equal the expected present value plus or minus one standard deviation, respectively. ${ }^{12}$

Our "benchmark" value for relative risk aversion is 3 , which is often used for representative-agent models. We solve all model variants for $\gamma$ between 2 and 10, viewed by Mehra and Prescott (1985) as the plausible range given the size of the stockholding "gamble". Initial wealth, $A_{0}$, is set to zero, unless otherwise noted. The rate of time preference is set at $3.13 \%$ per annum, around the values typically assumed, matching the estimate in Siegel (1993) for the historical average riskless rate over a very long horizon. The weight $\lambda$ given to bequests in final-period utility is assigned the benchmark value of 0.25 that gave plausible results in Bertaut and Haliassos (1997).

\section{Effects of Borrowing Constraints on Saving and on Portfolio Choice}

\subsection{Income-based constraints}

The introduction of an income-based borrowing constraint (see Section 2.1) discourages not only first-period borrowing but also stockholding and consumption, and results in higher financial net worth. Figure 1 shows wealth holding and portfolio composition under various degrees of constraint tightness for a high-school dropout with no initial wealth. It also includes wealth-to-income ratios of a "rich" household 
that has initial wealth equal to first-period income. The latter has positive unconstrained net wealth, as it desires to move resources to the future, and is only constrained if it faces very tight borrowing limits (i.e., very low $k$ ).

By contrast, the household with no initial wealth wants to borrow to finance stockholding and consumption in view of its expected increase in future labor income, and it expects its consumption to grow over time. Thus, when unconstrained (either facing no constraint or a constraint with $k$ exceeding 60\%), ${ }^{13}$ it desires to be a net borrower, and this makes it a good candidate for binding borrowing constraints.

When the household is unable to borrow as much as desired, it is forced to cut back both on stockholding and on current consumption (Fig. 1). The former happens because its ability to take advantage of low-interest borrowing to invest in stocks with higher expected yield is now being restricted. The latter is reflected in increased financial net worth. Even when no borrowing is allowed, i.e. $k=0$, households sacrifice some current consumption to invest in stocks, so as to take advantage of the equity premium. This holds even for relative risk aversion as high as 20 .

The reduction in stockholding and borrowing and the increase in net worth are monotonic in the tightness parameter $k$. Thus, the conjecture that households facing tighter constraints will reduce borrowing and stockholding is confirmed. Constrained net worth exceeds its unconstrained level, which is equivalent to saying that constrained households will consume less than desired in their first period of working life [equation (8)]. Current consumption is reduced by binding constraints even though the household could have preserved it by further cutbacks in the holdings of other assets. This happens although holdings of other assets cannot be used as collateral. The driving force behind this result is the expected return premium. 
Table 1 shows that the looser the constraint, the greater is expected future consumption and its ex ante variability, based on first-period information. Both effects are direct consequences of the result that looser constraints allow more current and expected future borrowing and stockholding, not only as levels but also as assetto-income ratios. The equity premium and the increased stockholding financed through debt create expectations of greater future consumption and larger bequests, but contribute to increased uncertainty.

The slopes of second-period asset-to-income ratios, plotted as functions of tightness $k$, depend on whether stock returns turned out to be high or low. In highreturn states, all asset-to-income ratios are larger the less tight the constraint; in lowreturn states, the opposite tends to be true. ${ }^{14}$ This can be explained as follows. A less tight constraint (larger $k$ ) means that the household was allowed to expose itself more to stockholding risk in its initial portfolio. As a result, the high-return states involve even bigger (and the low-return states even lower) realized wealth, as the constraint becomes less tight. Asset holdings are then positive functions of realized wealth.

As expected, less tight constraints are associated with higher expected lifetime utility, and actual utility in high-return second-period states. However, they imply more misery in low-return states, because they allow households to be less conservative with their portfolios in the first period of life.

Surprisingly, binding constraints can produce a reversal of the usual rankings of stockholding by risk aversion (Fig. 2). When the first-period constraint is binding, borrowing is equal to $k Y$. Regardless of constraint tightness, the more risk averse have higher net worth. Based on the findings of Haliassos and Hassapis (1997) for alternative preference specifications and no constraints, the main source of the higher net worth is that under expected utility the more risk averse have lower elasticity of 
substitution, which governs wealth-to-income ratios. We find here that this effect on wealth is so powerful for constrained households, as to dominate the downward pressure on stockholding generated by higher risk aversion.

\subsection{Collateral constraints}

Effects of collateral constraints (see Section 2.2) are qualitatively similar across education groups, and are illustrated by considering high-school graduates with risk aversion of 3 (Fig. 3). Again, we show the portfolio of a household without initial wealth, and wealth-to-income ratios for another with initial wealth equal to firstperiod income. The unconstrained wealth of the "rich" household is positive, and constraints do not bind for $b$ as low as 0.5 . However, the unconstrained solution for the other household, shown past the vertical line, implies substantial borrowing relative to current income, to finance consumption and risky asset holdings. As a result, unconstrained net worth is negative, making it a candidate for binding borrowing constraints over a wider range of tightness $b$.

Under a $100 \%$ collateral requirement, we have the familiar constraint $W_{t} \geq 0$ and $b=1$. Constrained consumption is equal to income, and net wealth is zero. Note, however, that this is the only specification of a collateral constraint for which these equalities hold, since constrained wealth in general is $(1-b) S$ and holdings of the collateral asset are positive. As we also found for income-based constraints, net worth is higher when constraints are tight enough to bind. The explanation in Section 4.1 is reinforced here by the attractiveness of the risky asset as collateral.

As the constraint is gradually relaxed from $b=0$, allowing the household to borrow a larger fraction of collateral, wealth holding decreases and therefore consumption (the difference between the given income and wealth holding) increases. ${ }^{15}$ For $b<1$, constrained net wealth is positive, and this means that all of borrowing and some part 
of labor income are devoted to financing the purchase of stocks, in order to build up collateral and to take advantage of the equity premium. ${ }^{16}$ For $b>1$, constrained net wealth is negative implying that consumption exceeds labor income and is partly financed through borrowing. The constraint is binding in at least one period or state ${ }^{17}$ for all runs shown using $b \leq 1.4$.

Interestingly, both stockholding and borrowing can "overshoot" their unconstrained levels. First-period stockholding attains its maximum (among the runs shown) for $b=1.1$, and then starts to fall towards its unconstrained value. ${ }^{18}$ The peak in borrowing occurs for a less tight constraint, at $b=1.3 .{ }^{19}$ When either stockholding or borrowing reaches its unconstrained level for the first time, consumption (wealth) is still below (above) its unconstrained value. The rise of consumption towards its desired level does not require a monotonic increase in borrowing, since stockholding also drops and this frees up resources. Stockholding can fall even while borrowing increases, since borrowing is given by $b S, b$ increases, and $S$ is already large. ${ }^{20}$

Ex ante consumption variability for the second and third periods is influenced, though not necessarily reduced, by binding borrowing constraints. The crucial aspect is not whether the constraint is binding per se, but whether it induces more limited exposure to debt and to stock return risk. For low $b$, when the constraint is tight and both stockholding and borrowing are limited, variability is well below the level corresponding to the unconstrained case. As the constraint becomes less tight, variability initially increases. At $b=1$, representing the constraint $W_{t} \geq 0$, variability is above its unconstrained value for all education levels. ${ }^{21}$ At higher $b$, when both firstperiod stockholding and borrowing are moderated, variability is somewhat reduced until it attains its unconstrained value. 
Figure 4 compares high-school dropouts with degrees of risk aversion equal to three and four. Even this small difference can influence whether the constraint is binding, as well as asset-to-income ratios. When risk aversion is 4 , constraints with $0 \leq b<1.3$ are binding, while the corresponding range for risk aversion of 3 is bigger $(0 \leq b<1.7)$. Lower risk aversion adds to the desire for borrowing more than it adds to tolerance of the risky asset, even with its dual role as collateral. Differences in risk aversion create wider portfolio disparities when constraints are less tight.

Figure 5 shows effects of education, which determines the stochastic process for income. Predictions are quite close, except for a range close to the threshold $b$ beyond which constraints do not bind. The already noted "overshooting" of risky asset holding and borrowing above their unconstrained levels is more pronounced for the more educated households. A key factor behind this result is the lower variance of both persistent and transitory income shocks facing households with higher education.

\section{Precautionary Motives}

Precautionary effects are measured as the difference in predictions between a model without income risk and one where expected income is the same but the household faces income risk. The presence of borrowing constraints introduces the possibility that such comparisons involve borrowing-constrained solutions or even one constrained and one unconstrained solution. In the latter case, the constraint is binding only in the absence of income risk, since the household is then more prone to borrow. This section shows that borrowing constraints can alter substantially the size and often the sign of precautionary effects, depending on their type and tightness. 


\subsection{Effects of introducing income-based constraints}

Figure 6 refers to high-school dropouts with no initial wealth and risk aversion

of 3. Similar pictures are obtained for all education categories, degrees of risk aversion, and for different levels of initial wealth, with adjustments to the values of $k$ at which constraints cease to be binding. The Figure shows that precautionary wealth is positive, regardless of whether constraints bind or not, but that it is smaller under binding constraints.

In the range of $k$ where constraints are not binding, the "temperance" effect of background income risk on desired stockholding (identified by Kimball, 1993) is quantitatively smaller than the effect of prudence. In other words, income risk curtails unconstrained stock demand by considerably less than it reduces borrowing (or increases riskless asset holdings). Indeed, since prudence boosts aggregate wealth but temperance reduces wealth (by reducing its risky component), this difference in size is necessary if we are to observe both a precautionary wealth buffer and a reduction in risky holdings among unconstrained households.

The conflict between prudence and temperance is taken to extremes when households are constrained facing income risk and without it. Since borrowing is at the (same) limit in both constrained solutions, a precautionary wealth buffer is not provided through reductions in borrowing. Instead, it is provided through increases in risky asset holdings. Prudence and temperance are no longer observed simultaneously: prudence prevails and temperance is reversed. Notice that this reversal occurs even though the household could generate precautionary wealth by decreasing borrowing below the allowable limit. It does not choose to do so, regardless of whether borrowing is used only to finance stockholding or also consumption. The increase in risky asset holdings is bigger for less tight (but binding) 
constraints. Faced with less tight constraints, households can both afford to buy more of the risky asset and feel more secure in doing so, since they can borrow more in future bad states. This reversal of temperance will have important empirical implications, discussed below.

For $k$ equal to 0.6 , the household with risky income becomes unconstrained, but it remains constrained with respect to the borrowing it would have undertaken if it were not faced with income risk. From this point on, the precautionary effect on bond holding increases and attains its maximum when the household becomes unconstrained even in the absence of income risk. Prior to this, the increase in precautionary wealth arises solely because the progressively more lax constraint allows the household to increase the borrowing it would have undertaken under no income risk. Its borrowing under income risk is already at its unconstrained level. The increase in riskless asset holding (reduction in borrowing) soon replaces risky asset holdings in providing for a precautionary wealth buffer, and temperance is restored.

\subsection{Effects of introducing collateral constraints}

Figure 7 shows precautionary effects under asset-based constraints for a household with less than high school education. Effects for other education groups are qualitatively similar. The constraint is not binding for values of tightness, $b$, to the right of the vertical line, regardless of whether income is risky or not. Under binding constraints, precautionary effects depend on collateral requirements, $b$.

The most commonly used constraint, $W_{t} \geq 0$ corresponding to $b=1$, yields constrained precautionary wealth equal to zero. The reason can be inferred from Fig. 7. Precautionary wealth is the difference between predicted wealth under income risk and under no income risk. For unconstrained solutions (to the right of the vertical line), removal of income risk increases desired borrowing more than desired 
stockholding. This is just another way of saying that desired precautionary wealth is positive. Thus, given that the household does not meet the collateral requirement under risky income, removal of income risk will generate a further shortfall of collateral (or, equivalently, a further drop in desired wealth). Since the constraint is binding under both risky and riskless income, net wealth is zero in both cases, and so is their difference, i.e. precautionary wealth. The Figure also shows the special nature of this constraint: for most degrees of tightness, precautionary wealth effects are positive, though smaller, than under non-binding constraints.

When collateral constraints are tight (low $b$ ), we observe a reversal of the negative precautionary effect on risky asset holdings, which parallels our finding for income-based constraints. In this range of $b$ values, the first-period borrowing constraint is binding regardless of whether income is risky or not. ${ }^{22}$ Constrained firstperiod wealth is equal to $(1-b) S$ (see section 2.2). The desire to build a precautionary wealth buffer (prudence) dominates the tendency to reduce exposure to risky assets in response to background labor income risk (temperance). ${ }^{23}$

It follows that there is also a reversal in the sign of precautionary effects on borrowing, as also seen in the Figure. Since first-period borrowing constraints are binding regardless of the presence of income risk in this range of $b$ values, borrowing is equal to $b S$. A positive precautionary effect on stockholding implies a positive effect on borrowing.

At higher values of $b$, when the constraint in the worst second-period state no longer binds, precautionary effects on stockholding and borrowing switch signs. Initially (around $b=1$ ), the reduction in borrowing is offset by a reduction in stockholding, without a change in consumption. For less tight $b$, however, riskless 
asset holdings (or equivalently reductions in borrowing) take on the brunt of providing precautionary wealth, which climbs up to its unconstrained value.

\section{Implications for Empirical Testing}

Two important issues arise in empirical testing of household saving and precautionary motives using modern household-level data. One is whether and how failure to distinguish between constrained and unconstrained households in a sample can bias empirical estimates of precautionary wealth accumulation and portfolio choice. The second is the practical issue of how to distinguish between constrained and unconstrained households in a sample. This section utilizes our findings in order to answer the first question and to discuss methods and complications regarding the second.

\subsection{Estimating Precautionary Effects}

Our findings suggest that if a sample of supposedly unconstrained households is contaminated with constrained ones due to imperfect allowance for borrowing constraints (see below), then estimates of the size of precautionary wealth effects will be biased downwards, and possibly insignificant. This is because precautionary wealth holdings were found to be nonnegative but smaller among constrained households than among their unconstrained counterparts of the same demographic and preference characteristics (see Figs. 6 and 7). Indeed, they were shown to be zero under binding constraints of the standard form $W_{l} \geq 0$.

Figs. 6 and 7 also suggest that some constrained households may exhibit positive precautionary effects on risky assets, unlike their unconstrained counterparts and some other constrained households. Given their sign ambiguity, contamination of the 
unconstrained sample may lead to the conclusion that income risk bears no systematic relationship to the demand for the risky asset or even a positive one. ${ }^{24}$

In Figs. 6 and 7, the size of precautionary effects crucially depends on the tightness of the constraint. Thus, credit conditions matter for the size of precautionary effects, not only by determining the proportion of constrained households but also by altering the tightness of binding constraints. There seems no reason to expect estimates of precautionary effects to be constant through time in countries experiencing changes in credit policy and financial market development. ${ }^{25}$

\subsection{Sample Splitting Criteria}

A number of empirical papers testing the PIH and a few estimating the size of precautionary saving and portfolio effects adopt the practice of splitting household samples into those likely to be constrained and unconstrained. Often, sample splits are based on comparisons, $W_{t} \geq x$, of asset holdings to some prespecified cutoff level (typically zero). A known criticism is that observed wealth, $W_{t}$, is itself endogenous. ${ }^{26}$ In this subsection, we argue that the appropriate cutoff, $x$, far from being universal, is itself endogenous and model-dependent in general.

A careful and highly influential paper of this type is Zeldes (1989b), in which households are classified as unconstrained if their relevant measure of current wealth exceeds two months' worth of (average past) income. ${ }^{27}$ Zeldes assumes that households have the same preference parameters and face the same constraint, $W_{t} \geq 0$, if any. Tests for the validity of first-order conditions rely on the consistency of parameter estimates for the unconstrained group under both the null of no constraints and the alternative. This in turn requires that the "unconstrained" group contain no currently constrained households. The analysis focuses on currently binding constraints, and results are broadly supportive of their presence, though not always 
consistent across different sample splits and tests. Our analysis suggests that use of a universal cutoff at zero may contaminate the unconstrained sample with constrained households and jeopardize the validity of tests for borrowing constraints. This may help explain the varying success of tests based on different sample splits.

Generally, the problem arises because constrained wealth is equal to $(1-b) S_{t}$ (or to $S_{t}-k Y_{t}$ under income-based constraints; see Figs. 1,2). Even when the researcher knows the institutionally relevant value of $b$ or $k$, the appropriate cutoff is neither preference- nor model-free in general. If all households indeed face the same $b$ or $k$, the cutoff depends on the endogenous value of $S_{t}$. If some face tighter borrowing constraints than others and/or credit conditions evolve over time, then $b$ and $k$ are also household- and time-dependent. Part of the appeal for using tests based on first-order conditions is lost, as they may not eliminate the need for explicit consideration of the income process and other characteristics at the preliminary stage of sample splitting.

Figure 4 shows the effects of a small difference in relative risk aversion (3 versus 4) under collateral constraints. The less risk averse tend to borrow more, invest more in stocks, and have lower net wealth. Thus for $b \neq 1$, risk aversion tends to influence both whether a particular household is constrained, and its asset holdings. If the constraint is tighter than $W_{t} \geq 0$ (i.e., $b<1$ ), then a cutoff wealth level at zero would include in the supposedly unconstrained subsample the "rich" unconstrained households with positive wealth shown in Fig. 3, but also constrained agents with risk aversion of 3 or 4 .

If households face heterogeneous constraints, Figs. 1-4 imply that setting a universal cutoff level at zero contaminates the unconstrained sample with households that have positive wealth precisely because they face tighter, binding constraints than $W_{t} \geq 0$. Moreover, the extent of sample contamination can vary over time as credit 
markets (and $b$ and $k$ ) evolve. It is even possible for some unconstrained households to be excluded if their preferences induce them to be net borrowers.

The intertemporal nature of the saving-portfolio problem further reduces the appropriateness of numerical cutoffs. Fig. 8 shows wealth-to-income ratios for a highschool dropout, unconstrained in its second period of working life, as a function of the return-income state realized. For $k$ shown below 0.6 (in both periods), the constraint was binding in the first period. It is clear that current unconstrained status is consistent with a variety of wealth levels, depending on whether the borrowing constraint was binding in the first period. ${ }^{28}$ It is even possible for households to be unconstrained currently and in the past (facing constraints to the right of the vertical line), and to hold smaller wealth than others previously constrained (to the left of the vertical line).

Table 2 uses data from the 1995 Survey of Consumer Finances to illustrate the possible magnitude of misclassification when using a universal cutoff level close to zero (at two months' worth of last year's income). ${ }^{29}$ It compares this criterion to one based on direct Survey responses indicating binding constraints and controls for age and education. ${ }^{30}$ Predictably, the percentage of constrained households based on either criterion falls as education or age rise. Comparison of the first two rows, however, indicates that the wealth-based criterion tends to classify significantly more households as constrained than implied by Survey responses. More striking is the third row, which shows the extent of contamination of the "unconstrained" sample selected on the basis of wealth, with households that actually responded they were constrained. The problem is especially acute for lower education and younger households, among which liquidity constraints are more prevalent. The last row shows that a significant percentage of those who did not indicate binding constraints 
in their Survey responses are classified as being constrained by the asset-based criterion simply because they have very low wealth.

If $b$ and $k$ are known to the researcher and common to all households, modelfree sample-splitting criteria can still be specified, but they are portfolio restrictions. ${ }^{31}$ To be included in the unconstrained group, a household should have net wealth above $(1-b) S_{t}$ (or $S_{t}-k Y_{t}$ respectively).This criterion reduces to nonnegativity only if institutions require $b$ equal to one (i.e., a $100 \%$ collateral requirement). Problems arising from heterogeneous constraints can also be avoided by portfolio restrictions, but this now requires knowledge of the household-specific $b$ or $k$ values.

Barring direct knowledge of the nature and history of constraints, a researcher may adopt a conservative approach of including in the unconstrained subsample only households that satisfy portfolio restrictions for large $b$ or $k$. However, when preference heterogeneity is prevalent, this tends to select those who simply prefer to borrow a lot. Testing the validity of first-order conditions might still be warranted, but using preference parameter estimates from the unconstrained subsample to test the validity of the same conditions in the rest of the sample would appear problematic.

There remains the issue of detecting binding constraints expected in some future states or in states that did not materialize. Although these tend to influence behavior of currently unconstrained households, there are no data to examine portfolio restrictions. Direct survey questions regarding expectations, motives for saving, and past experience with credit constraints can be useful, but it is unlikely that they will cover the entire span of time periods and contingencies incorporated in intertemporal models in order to identify globally unconstrained households. ${ }^{32}$ The biases identified in Section 6.1 are likely to persist, unless accurate indicators of constraints are used or tests are devised that do not rely on the absence of constrained agents. ${ }^{33}$ 


\section{Concluding Remarks}

Our findings suggest that borrowing constraints, either income-related or asset-based, can have substantial influence on household saving, portfolio choice, and on the size and direction of precautionary effects. This influence varies with their degree of tightness. The popular nonnegativity constraint on net wealth turns out to be quite special in implying not only equality of consumption to income but also the absence of precautionary effects on wealth. The often assumed borrowing ceiling at zero implies smaller precautionary wealth than constraints relating borrowing ceilings to income or collateral, and it reverses the sign of precautionary effects on risky asset holding. More generally, standard temperance effects on risky assets, arising from the introduction of background income risk, are reversed if the desire to avoid exposure to additional financial risk is dominated by the motive to build up precautionary wealth. We found this to be the case for income based constraints that are binding in the presence of income risk, and for a subset of collateral constraints. When temperance is reversed, collateral constraints reverse the sign of precautionary effects for borrowing, as well.

Thus, erroneous inclusion of constrained households in an unconstrained sample is likely to bias downwards estimates of precautionary effects on wealth, and to yield small or insignificant estimates of precautionary effects on risky asset holding and on borrowing. Identifying globally unconstrained households, over time and across the state space, with a high degree of accuracy is worthwhile but challenging. Taken together, these findings point to a possible explanation for the failure of recent empirical studies to uncover sizeable precautionary effects on saving and portfolios. 


\section{References}

Alessie, R., M.P. Devereux, and G. Weber, 1997, Intertemporal consumption, durables, and liquidity constraints: A cohort analysis, European Economic Review, 41, 37-59.

Attanasio, Orazio, James Banks, and Sarah Turner, 1998, Asset holding and consumption volatility, mimeo.

Bacchetta, Philippe, and Stefan Gerlach, 1997, Consumption and credit constraints: International evidence, Journal of Monetary Economics, 40, 207-38.

Bertaut, Carol, 1998, Stockholding behavior of U.S. households: Evidence from the 1983-89 Survey of Consumer Finances, Review of Economics and Statistics, 80, 263-75.

Bertaut, Carol and Michael Haliassos, 1997, Precautionary portfolio behavior from a life-cycle perspective, Journal of Economic Dynamics and Control, 21, 1511-42.

Bodie, Z., W. Samuelson, and R. Merton, 1992, Labor supply flexibility and portfolio choice in a life-cycle model, NBER Working Paper \# 3954.

Carroll, Chris, 1992, The buffer stock theory of saving: Some macroeconomic evidence, Brookings Papers on Economic Activity, 1992:2, 61-135.

Carroll, Chris, 1997, Buffer Stock Saving and the Permanent Income Hypothesis, Quarterly Journal of Economics, 112, 1-56.

Constantinides, G.M., J.B. Donaldson, and R. Mehra, 1998, Junior can't borrow: A new perspective on the equity premium puzzle, mimeo.

Chah, E.Y., V.A. Ramey, and R.M. Starr, 1995, Liquidity constraints and intertemporal consumer optimization: Theory and evidence from durable goods, Journal of Money, Credit, and Banking, 27, 272-87.

Deaton, Angus, 1991, Saving and liquidity constraints, Econometrica, 59, 1221-48.

Deaton, Angus, 1992, Understanding Consumption, Oxford University Press.

Gakidis, Haralabos, 1998, Stocks for the old? Earnings uncertainty and life-cycle portfolio choice, mimeo.

Guiso, Luigi, Tullio Jappelli, and Daniele Terlizzesse, 1992, Earnings uncertainty and precautionary saving, Journal of Monetary Economics, 30, 307-21.

Guiso, Luigi, Tullio Jappelli, and Daniele Terlizzesse, 1996, Income risk, borrowing constraints, and portfolio choice, American Economic Review, 86, 158-72.

Haliassos, Michael, 1994, On perfect foresight models of a stochastic world, The Economic Journal, 104, 477-91.

Haliassos, Michael and Carol C. Bertaut, 1995, Why do so few hold stocks?, The Economic Journal, 105, 1110-1129.

Haliassos, Michael and Christis Hassapis, 1997, Non-expected utility, saving, and portfolio choice, mimeo. 
Hochguertel, Stefan, 1998, Household's Portfolio Choices, Unpublished Doctoral Dissertation, Tilburg University, The Netherlands.

Hubbard, R. Glenn, Jonathan Skinner, and Steven Zeldes, 1994, The importance of precautionary motives in explaining individual and aggregate saving, CarnegieRochester Conference Series on Public Policy, 40, 59-125.

Jappelli, Tullio, Steffen Pischke, and Nick Souleles, 1998, Testing for liquidity constraints in Euler equations with complementary data sources, Review of Economics and Statistics, $80,251-62$.

Kimball, Miles, 1990, Precautionary saving in the small and in the large, Econometrica, 58, 5373.

Kimball, Miles, 1993, Standard risk aversion, Econometrica, 61, 589-612.

King, Mervyn and Jonathan Leape, 1984, Wealth and portfolio composition: theory and evidence, NBER Working Paper 1468.

Koo, H.K., 1991, Consumption and Portfolio Choice with Uninsurable Income Risk, mimeo.

Leland, Hayne, 1968, Saving and uncertainty: The precautionary demand for saving, Quarterly Journal of Economics, 82, 456-73.

Ludvigson, Sydney, 1998, Consumption and credit: A model of time-varying liquidity constraints, forthcoming in The Review of Economics and Statistics.

Mankiw, N. Gregory, and Steven Zeldes, 1991, The consumption of stockholders and nonstockholders, Journal of Financial Economics, 29, 97-112.

Marcet, Albert and Kenneth Singleton, 1991, Equilibrium asset prices and saving of heterogeneous agents in the presence of incomplete markets and portfolio constraints, mimeo.

Meghir, Costas and Guglielmo Weber, 1996, Intertemporal nonseparability or borrowing restrictions? A disaggregate analysis using a U.S. consumption panel, Econometrica, 64, 1151-81.

Mehra, Rajnish and Edward Prescott, 1985, The equity premium: A puzzle, Journal of Monetary Economics, 15. 145-61.

Muellbauer, J. and R. Lattimore, 1995, The consumption function: A theoretical and empirical overview. In Pesaran, H. and M.R. Wickens (Eds.), Handbook of Applied Econometrics: Macroeconomics, Blackwell Publishers, 211-311.

Paxson, Christina, 1990, Borrowing Constraints and Portfolio Choice, Quarterly Journal of Economics, 535-43.

Poterba, James and Andrew Samwick, 1995, Stock Ownership Patterns, Stock Market Fluctuations, and Consumption, Brookings Papers on Economic Activity, 2, 295-357.

Sandmo, Agnar, 1970, The effect of uncertainty on saving decisions, Review of Economic Studies, 37, 353-60. 
Schwert, G.William, 1990, Indexes of U.S. stock prices from 1802-1987, Journal of Business, $63,399-426$.

Siegel, Jeremy, 1992, The real rate of interest from 1800-1990: A study of the U.S. and the U.K., Journal of Monetary Economics, 29, 227-52.

Zeldes, Steven, 1989a, Optimal consumption with stochastic income: Deviations from certainty equivalence, Quarterly Journal of Economics, 275-98.

Zeldes, Steven, 1989b, Consumption and liquidity constraints: An empirical investigation, Journal of Political Economy, 305-46. 
Table 1

Effects of the Tightness of Income Based Constraints on Endogenous Variables

\begin{tabular}{|c|c|c|c|c|c|c|}
\hline$k$ & 0.1 & 0.2 & 0.3 & 0.4 & 0.5 & 0.6 \\
\hline $\bar{W} / \mathrm{Y}$ & 0.009 & -0.040 & -0.090 & -0.130 & -0.170 & -0.190 \\
\hline $\mathrm{S} / \mathrm{Y}$ & 0.109 & 0.160 & 0.210 & 0.270 & 0.330 & 0.400 \\
\hline $\mathrm{B} / \mathrm{Y}$ & -0.100 & -0.200 & -0.300 & -0.400 & -0.500 & -0.600 \\
\hline $\mathrm{E}\left(\mathrm{C}_{2}\right)$ & 18702 & 19254 & 19884 & 20664 & 21655 & 22753 \\
\hline $\operatorname{Std}\left(C_{2}\right) / E\left(C_{2}\right)$ & 0.26 & 0.27 & 0.30 & 0.33 & 0.37 & 0.41 \\
\hline $\mathrm{E}\left(\mathrm{C}_{3}\right)$ & 19972 & 20640 & 21428 & 22269 & 23337 & 24520 \\
\hline $\operatorname{Std}\left(C_{3}\right) / E\left(C_{3}\right)$ & 0.51 & 0.53 & 0.54 & 0.56 & 0.59 & 0.62 \\
\hline $\mathrm{E}$ (Bequests) & 13848 & 14311 & 14857 & 15440 & 16181 & 17001 \\
\hline $\operatorname{Std}(\mathrm{Beq}) / \mathrm{E}(\mathrm{Beq})$ & 0.51 & 0.52 & 0.54 & 0.56 & 0.59 & 0.62 \\
\hline $\mathrm{E}(\mathrm{W} / \mathrm{Y})_{2}$ & 0.30 & 0.32 & 0.35 & 0.40 & 0.46 & 0.52 \\
\hline $\mathrm{E}(\mathrm{S} / \mathrm{Y})_{2}$ & 0.23 & 0.24 & 0.26 & 0.27 & 0.29 & 0.31 \\
\hline $\mathrm{E}(\mathrm{B} / \mathrm{Y})_{2}$ & 0.07 & 0.07 & 0.09 & 0.12 & 0.16 & 0.21 \\
\hline $\mathrm{W}^{1} / \mathrm{Y}^{1}$ & 0.46 & 0.51 & 0.57 & 0.64 & 0.72 & 0.81 \\
\hline $\mathrm{W}^{2} / \mathrm{Y}^{2}$ & 0.30 & 0.28 & 0.26 & 0.24 & 0.23 & 0.22 \\
\hline $\mathrm{W}^{3} / \mathrm{Y}^{3}$ & 0.40 & 0.51 & 0.65 & 0.81 & 1.00 & 1.20 \\
\hline $\mathrm{W}^{4} / \mathrm{Y}^{4}$ & 0.07 & 0.002 & -0.05 & -0.09 & -0.12 & -0.15 \\
\hline Exp. Lifetime U & 16099 & 16558 & 16896 & 17121 & 17245 & 17278 \\
\hline $\mathrm{U}^{1}$ & 26017 & 27535 & 29260 & 31355 & 33842 & 36455 \\
\hline $\mathrm{U}^{2}$ & 21225 & 20672 & 20141 & 19652 & 19207 & 18854 \\
\hline $\mathrm{U}^{3}$ & 17551 & 19069 & 20794 & 22889 & 25376 & 27989 \\
\hline $\mathrm{U}^{4}$ & 12653 & 12185 & 11675 & 11186 & 10741 & 10388 \\
\hline
\end{tabular}

Notes: 1. Std stands for Standard Deviation, Beq. stands for Bequest, W stands for Wealth, S for Stocks, B for Bonds, $\mathrm{U}$ for Utility, $\mathrm{C}$ for Consumption and $\mathrm{k}$ is the maximum proportion (or multiple) of income one can borrow according to $-\mathrm{B}_{\mathrm{t}} \leq \mathrm{kY}, \mathrm{k}>0$.

2. Superscripts denote states, subscripts denote time periods. 
Table 2: Comparison of Survey Responses on Constraints to Wealth-based Sample Splitting

\begin{tabular}{||l|c|c|c|c|c|c|c|c|c|}
\hline $\begin{array}{l}\text { Education of } \\
\text { Household Head }\end{array}$ & \multicolumn{3}{|c|}{$\begin{array}{c}\text { Less than } \\
\text { High School }\end{array}$} & \multicolumn{3}{c|}{ High School } & \multicolumn{3}{c|}{ College or More } \\
\hline Age & $<40$ & $40-59$ & $>60$ & $<40$ & $40-59$ & $>60$ & $<40$ & $40-59$ & $>60$ \\
\hline $\begin{array}{l}\text { Constrained based } \\
\text { on W criterion (\%) }\end{array}$ & 90 & 74 & 49 & 71 & 54 & 27 & 53 & 34 & 12 \\
\hline $\begin{array}{l}\text { Constrained based } \\
\text { on Responses (\%) }\end{array}$ & 49 & 29 & 11 & 42 & 24 & 5 & 25 & 16 & 6 \\
\hline $\begin{array}{l}\text { Percent of } \\
\text { unconstrained by } \\
\begin{array}{l}\text { W, but constrained } \\
\text { based on Response }\end{array}\end{array}$ & 52 & 20 & 5 & 29 & 15 & 4 & 16 & 9 & 4 \\
\hline $\begin{array}{l}\text { Percent of those } \\
\text { reporting } \\
\text { unconstrained but } \\
\text { classified as } \\
\text { Constrained by W } \\
\text { criterion }\end{array}$ & 91 & 71 & 45 & 65 & 48 & 26 & 48 & 28 & 11 \\
\hline \hline
\end{tabular}

Source: 1995 Survey of Consumer Finances.

Notes: W criterion classifies as credit constrained those with wealth less than or equal to 2 months' worth of last year's income. Response criterion classifies as credit constrained those who responded that they were denied credit or received less credit than requested (and did not subsequently reapply or apply elsewhere and receive full amount) or did not apply because they thought that the application would be rejected. 
FIGURE 1

Portfolios Under Income Based Constraints

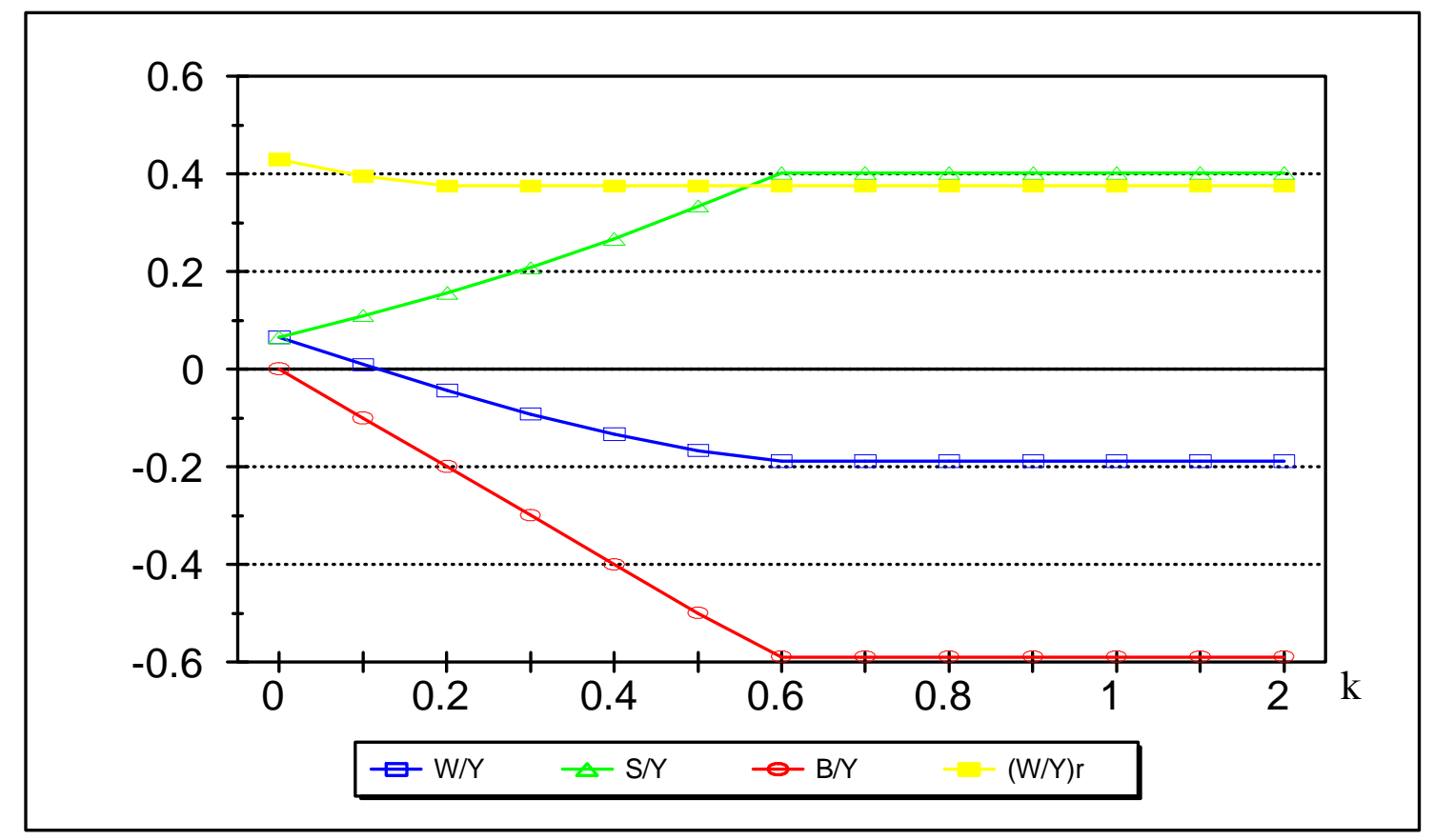

W/Y stands for the Wealth to Income Ratio, S/Y for the Stocks to Income ratio, and $\mathrm{B} / \mathrm{Y}$ for the Bonds to Income Ratio. High-school dropouts. (W/Y)r refers to households with initial wealth equal to first-period income.

FIGURE 2

Portfolios Effects of Risk Aversion Under Income-based Constraints

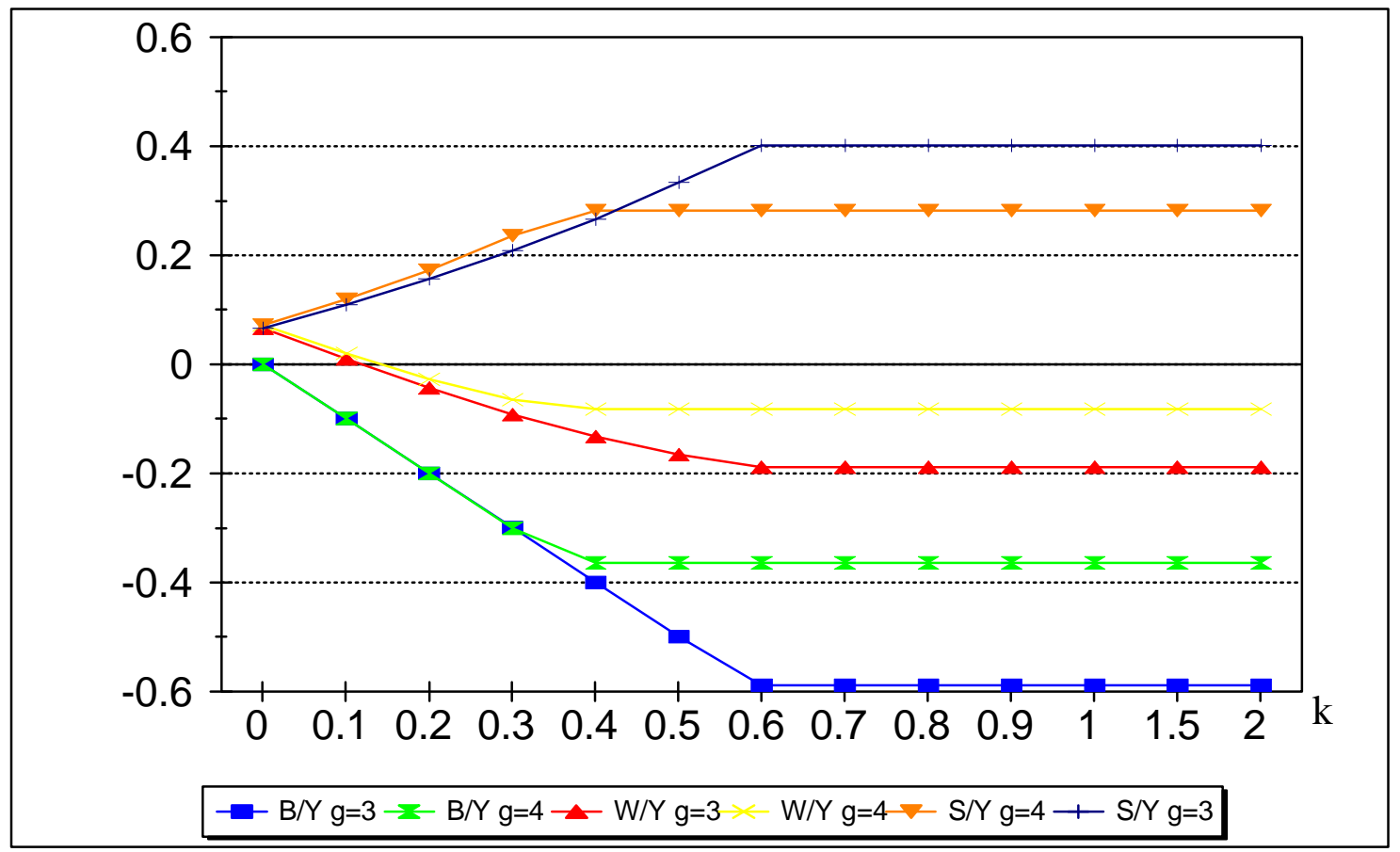

g stands for the Risk Aversion Coefficient. High-school dropouts. 
FIGURE 3

Portfolios Under Asset Based Constraints

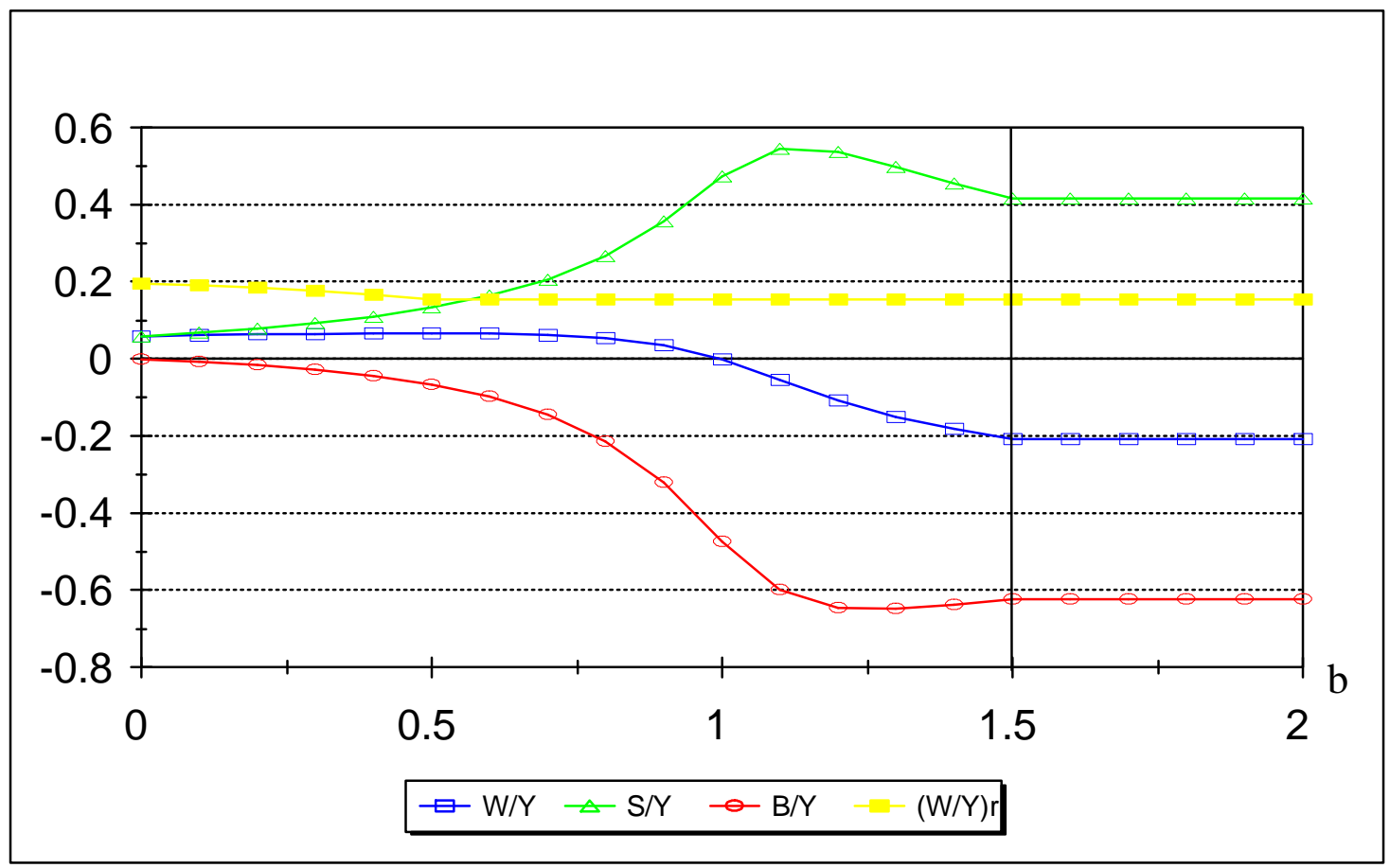

Portfolios of high-school graduates. (W/Y)r refers to households with initial wealth equal to first-period income.

FIGURE 4

Portfolio Effects of Risk Aversion under Asset Based Constraints

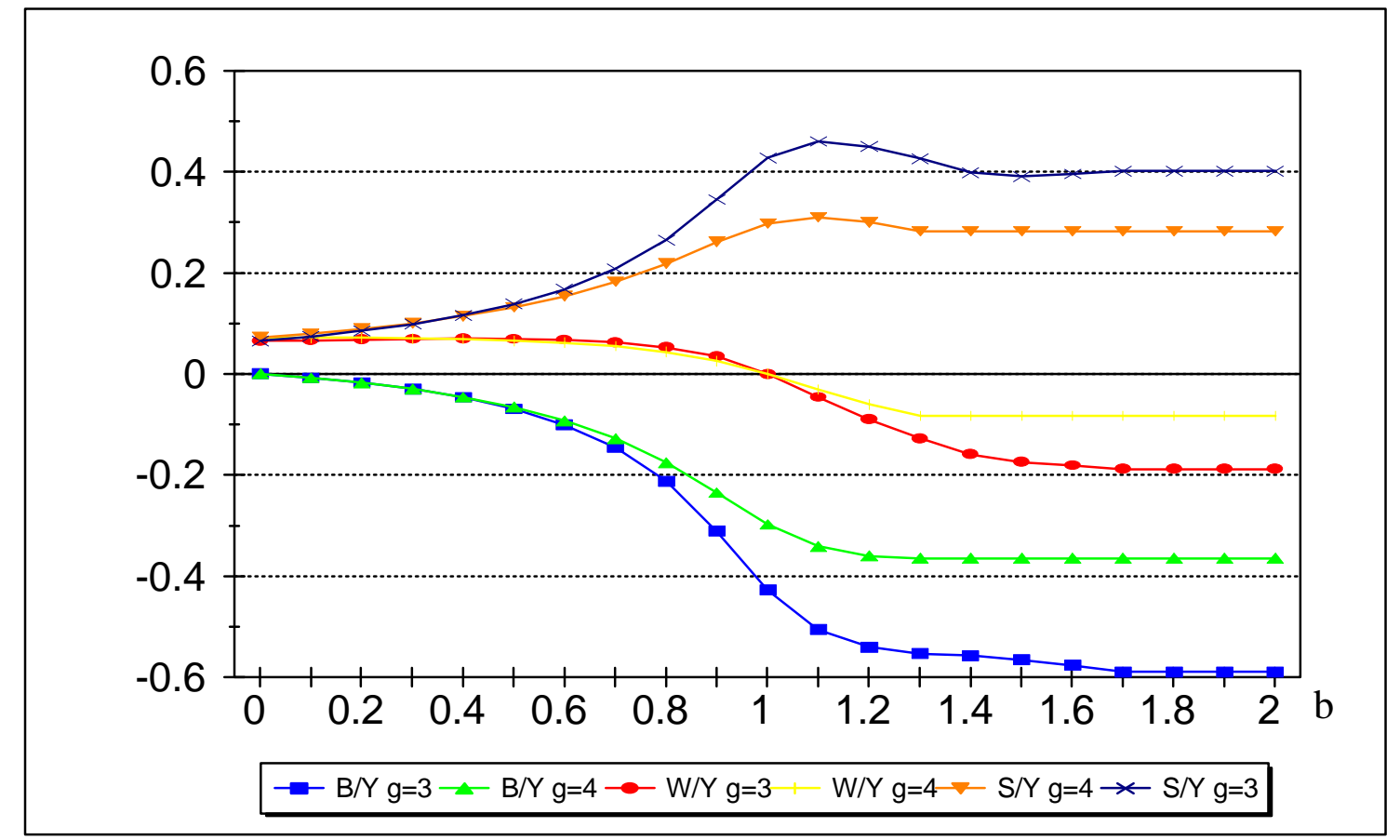

Portfolios of high-school graduates. 
FIGURE 5

Portfolios Effects of Income Processes and Asset-Based Constraints

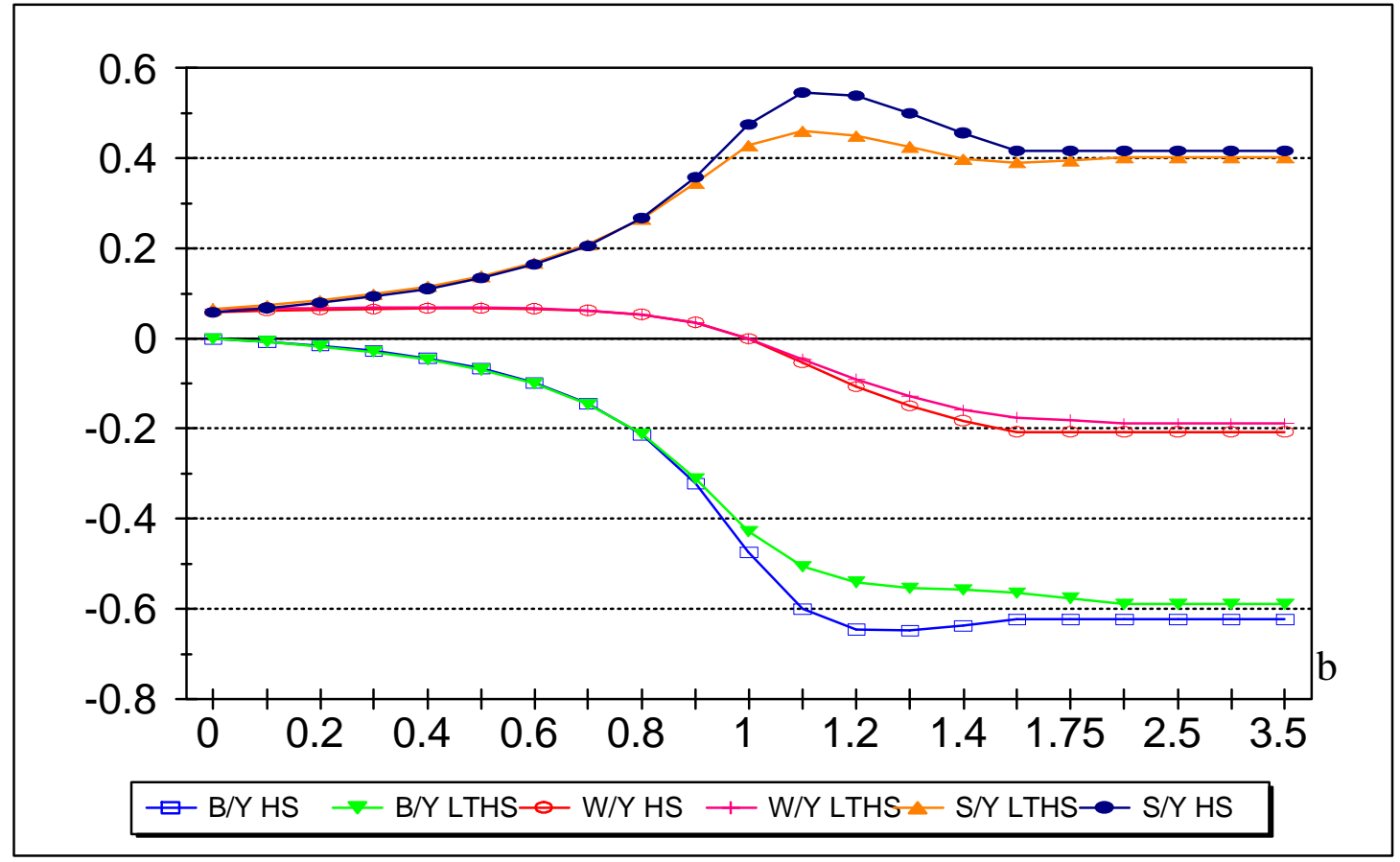

LTHS and HS stand for Less than High School and High School Education. Risk aversion is equal to 3 .

FIGURE 6

Precautionary Effects under Income Based Constraints

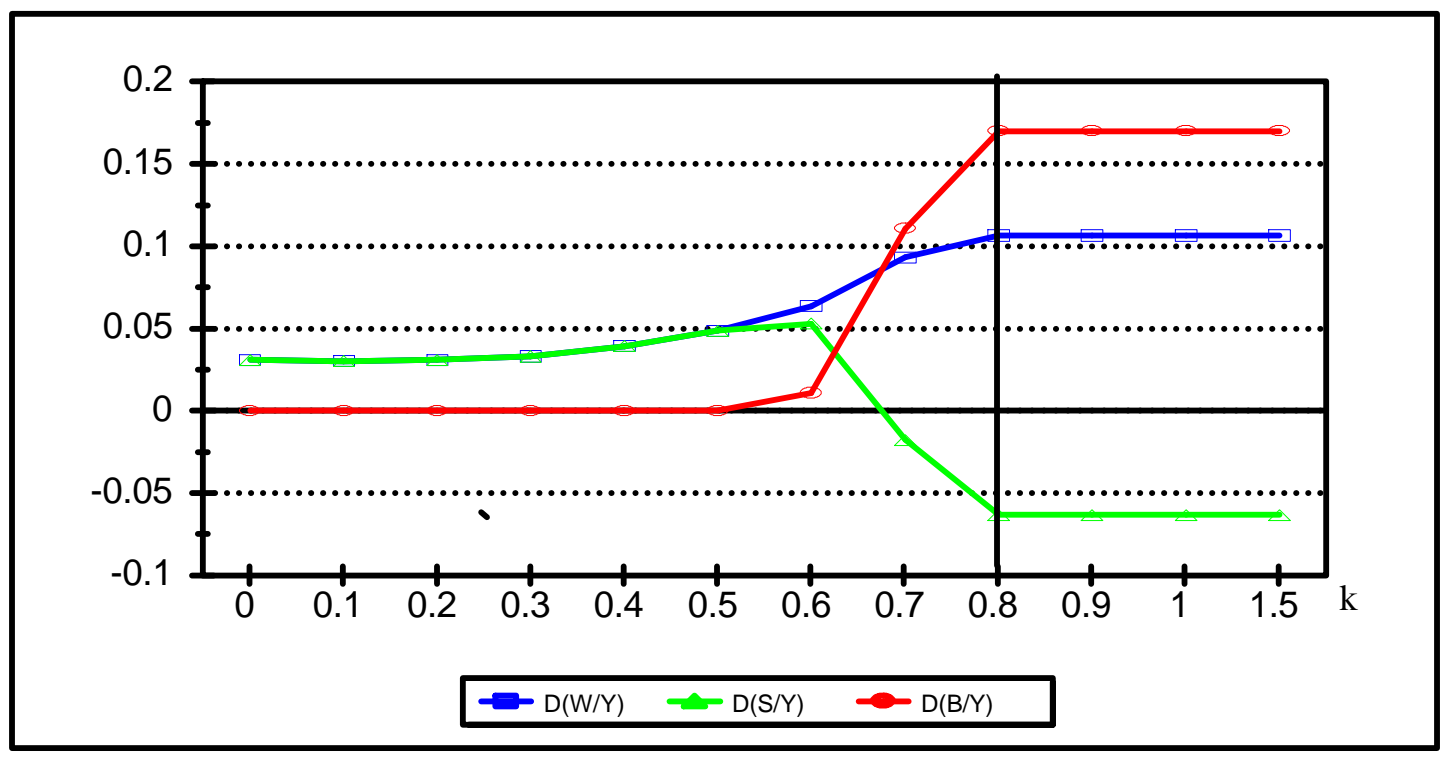

$\mathrm{D}(\ldots / \ldots)$ stands for the Precautionary Effect on the Corresponding Ratio. High-school dropouts with risk aversion of 3 . 
FIGURE 7

Precautionary Effects Under Asset Based Constraints

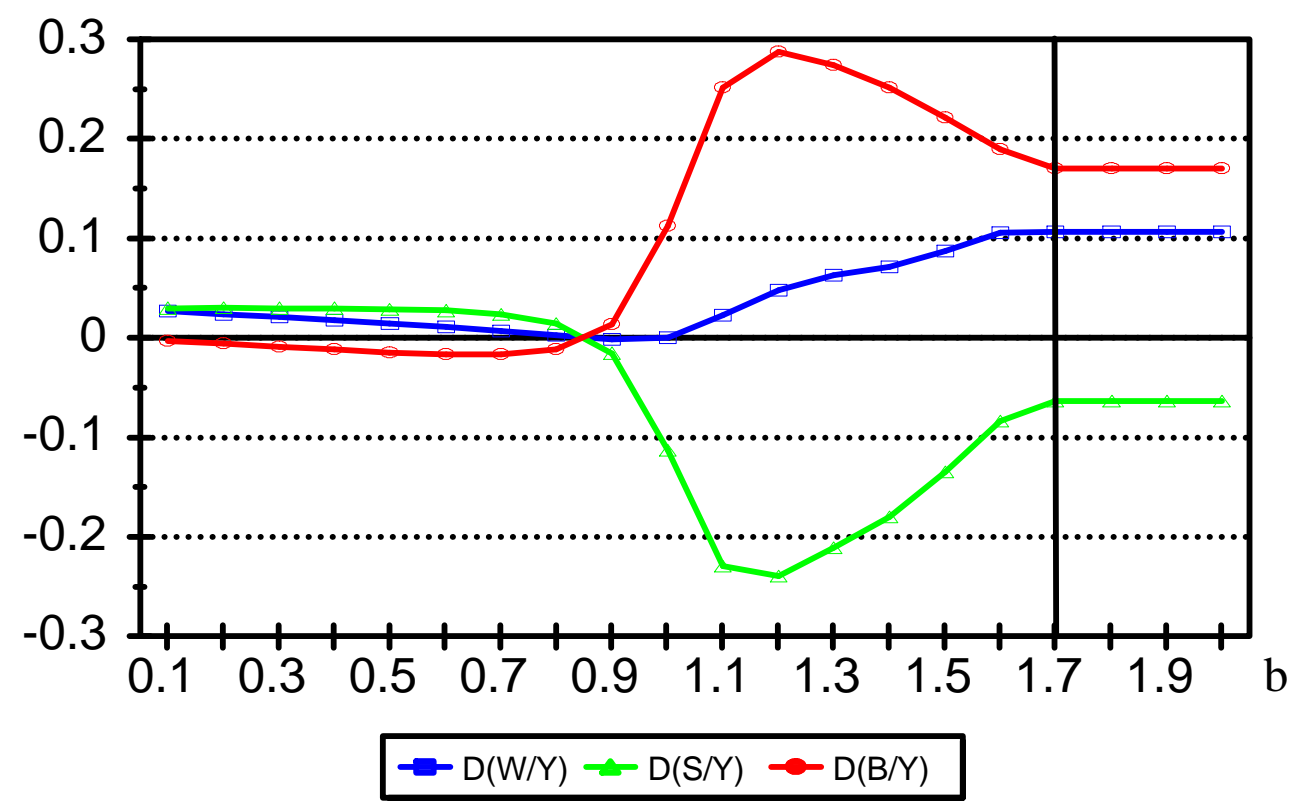

High-school graduates with risk aversion of 3 and no initial wealth.

FIGURE 8

State-dependent Wealth to Income Ratios in the Second Period

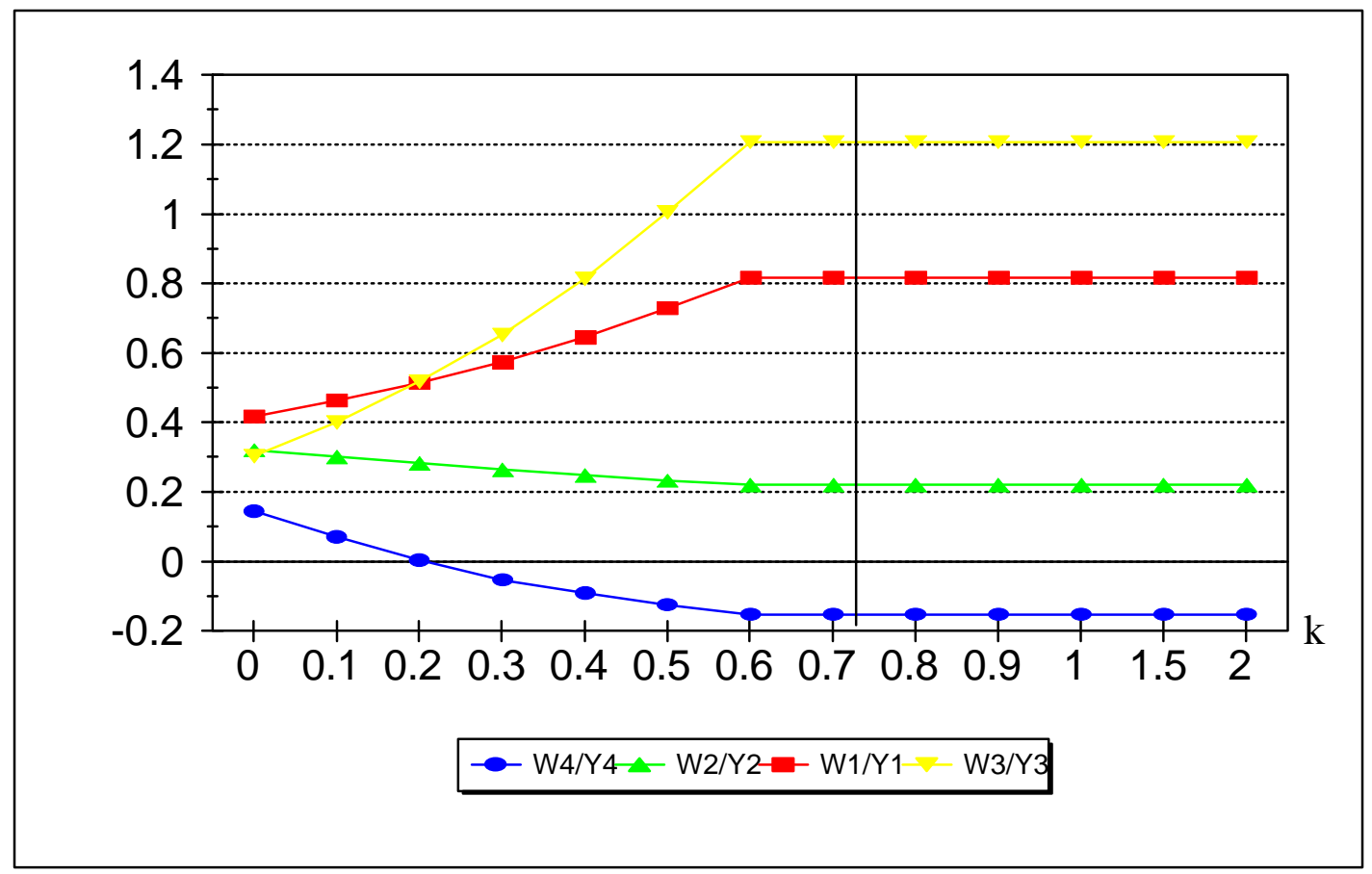

W/Y stands for wealth to income ratios in the four possible second-period states. State 1: high stock return, high income; State 2: low stock return, high income; state 3: high stock return, low income; state 4: low stock return, low income. 


\section{Endnotes}

${ }^{1}$ Pioneers in building single-asset, precautionary saving models were Leland (1968) and Sandmo (1970), to be followed by a number of subsequent contributors (e.g., Kimball, 1990, 1993; Zeldes, 1989a; Carroll, 1992, 1997; Hubbard, Skinner, and Zeldes, 1994).

${ }^{2}$ For surveys, see Bacchetta and Gerlach, 1997; Deaton, 1992; Muellbauer and Lattimore, 1995.

${ }^{3}$ See, for example, Alessie et al. (1997); Bacchetta and Gerlach (1997); Chah et al. (1995); Ludvigson, (1998).

${ }^{4}$ Contributions to this literature include Mehra and Prescott, 1985; Mankiw and Zeldes, 1991; Attanasio, Banks, and Turner, 1998; Haliassos and Bertaut, 1995, 1997; Poterba and Samwick, 1995; Bertaut, 1998; Haliassos and Hassapis, 1997; Hochguertel, 1998).

${ }^{5}$ For example, Marcet and Singleton (1991) argue that financial institutions commonly impose a constraint that the costs of servicing personal debt not exceed one-third of personal income. In their case as in ours, of one-period debt, the constraint applies to the repayment of principal and interest on loans. Ludvigson (1998) models the credit limit as a function of current income. A difference between both of these papers and ours is the length of the time period considered. Since ours is a long-run model of twenty-year periods, it does not necessarily imply year-by-year variation of credit limits depending on the income shocks experienced during each year. It rather relates borrowing over the entire period to the present value of incomes obtained, taking into account both transitory and persistent income shocks insofar as they influence the longer-term income measure.

${ }^{6}$ Even under endogenous labor-leisure choice, what matters for credit limits in our model is the longerrun career outcome rather than short-term fluctuations in labor supply. The assumption of exogenous labor income is typically made in models with nondiversifiable labor income risk. For an exception, but without borrowing constraints, see Bodie et al. (1992).

${ }^{7}$ In what follows, we consider only one-period loans, where the period is long. Thus, the amount of borrowing undertaken in each period (a flow) is equal to the amount of debt (a stock) that will be held between the current period and the next. Thus, we will be using "borrowing" and "debt" interchangeably, unless there is a reason to differentiate them.

${ }^{8}$ In multi-asset models, it is even possible to expand the constraint specification introducing different parameters $b_{i}$ for each collateral asset $i$.

${ }^{9}$ Using stocks as collateral for consumer loans may appear somewhat artificial, although it is often an implicit assumption in models with bonds and stocks. As a matter of fact, the financial services sector offers such possibilities to consumers. Citibank, for example, offers to consumers the possibility of using stocks as collateral for loans, so that consumers can avoid liquidating them and having to pay transactions costs and capital gains taxes. The accounts contain provisions for adjusting the units of stock placed as collateral when stock prices (and hence collateral values) change.

${ }^{10}$ For a discussion of some issues arising from taxation of capital gains, see Haliassos and Lyon (1994).

${ }^{11}$ As the introduction of lognormally distributed shocks alters expected incomes, suitable adjustments are made to the income values used in calibration so as to remove this effect (see Bertaut and Haliassos, 1997).

${ }^{12}$ In our calibrations, we use the following income values, scaled to represent incomes which if received each year over a twenty-year period would yield the present values derived in our stochastic simulations. $\mathrm{Y}_{\mathrm{t}}$ refers to income in period $t$, while $h$ and $l$ refer to the high and low income states respectively. For high-school dropouts, $\left[\mathrm{Y}_{1}, \mathrm{Y}_{2 \mathrm{~h}}, \mathrm{Y}_{2 \mathrm{l}}, \mathrm{Y}_{3}\right]=[15019,30088.5,13219.5,13633]$. In models without income risk, $Y_{2}=21570$. For high-school graduates, $\left[\mathrm{Y}_{1}, \mathrm{Y}_{2 \mathrm{~h}}, \mathrm{Y}_{21}, \mathrm{Y}_{3}\right]=[25920,48691$, 26219, 22032] and $Y_{2}=37583$. For College graduates, $\left[Y_{1}, Y_{2 h}, Y_{2 l}, Y_{3}\right]=[39483,96010,55338,49663]$ and $\mathrm{Y}_{2}=75527$.

${ }^{13}$ When discussing cutoff values of constraint tightness parameters $b$ and $k$ we refer to the calibration experiments shown on the Figures (as highlighted points on the various schedules). It is possible, but probably not worthwhile, to be more exact in depicting cutoffs by running experiments for finer parameter grids.

${ }^{14}$ This monotonicity result is violated only for the stock-to-income ratio in the worst state that involves low incomes and low stock returns.

${ }^{15}$ We have found an exception for a small segment at very low $b$ values where wealth rises slightly and then falls. In this range of very low $b$ 's, both borrowing and stockholding are small. Relaxation of the constraint encourages investment in the risky asset offering the return premium and this effect slightly dominates the downward pressure on wealth because of increased borrowing. As stockholding becomes more sizeable, the magnitude of effects is reversed. 
${ }^{16}$ It may seem unintuitive that households are constrained to have positive net wealth. In fact, they are only constrained to have net wealth equal to (1-b) $S_{t}$, but they choose to hold a positive amount of the collateral asset, partly because of its return premium and partly because of its usefulness as collateral.

${ }^{17}$ For runs shown with $b \leq 0.3$, exposure to debt and to stockholding risk is substantial and causes the borrowing constraint to bind in the worst second period state when both income and asset returns are low. For $0.4 \leq b \leq 1.4$, the constraint binds only in the first period, while no constraint binds for $b \geq 1.5$.

18 The same pattern is followed by stock- and bond-to-income ratios in the second-period states involving high stock returns. The corresponding ratios for the second-period states involving low stock returns fall throughout this range of $b$.

${ }^{19}$ This is easy to see algebraically. Stockholding, as a function of constraint tightness, is $S(b)$, and it peaks when $S^{\prime}(b)=0$. Constrained bondholding is equal to $-b S(b)$, representing borrowing, and its slope is $-S(b)-b S(b)$, which is equal to $-S(b)<0$ when stockholding peaks.

${ }^{20}$ Although this phenomenon is of interest as a possibility, we have not found it to be an inescapable feature of collateral constraints. It seems to vanish for households with high initial wealth, which suggests that it is more likely to apply to collateral holdings of households with low initial resources.

${ }^{21}$ This is consistent with the finding of Koo (1991) who had focused exclusively on the case $b=1$ in a continuous-time, infinite-horizon setup and found that borrowing constraints increase the variability of the growth rate of consumption. Our findings suggest, however, that the sign and magnitude of the effect depend on the degree of tightness of the constraint.

${ }^{22}$ Under income risk, the borrowing constraint in the worst second-period state is also binding.

${ }^{23}$ Interestingly, Koo (1991) had found such a positive effect on stockholding in his infinite-horizon, continuous-time framework, but for the case $b=1$, which was the only case he considered. The reversal occurred only for a low ratio of initial wealth to income. In our benchmark calibration setups, this ratio is zero, and the reversal is not observed for $b=1$ but only for tighter constraints. The finding suggests that the reversal is not necessarily associated with constraints of the form $W_{t} \geq 0$ and low initial wealth, but it is a function of preference and income process parameters as they relate to initial wealth and to the tightness of the constraint.

${ }^{24}$ For example, Hochguertel (1998) occasionally finds positive effects when not allowing for liquidity constraints.

${ }^{25}$ Of course, saying that liquidity constraints would introduce coefficient biases does not necessarily imply that small estimated effects imply the existence of liquidity constraints. It is possible that other factors can be identified in future research, which are also consistent with observed estimates. However, the findings of Haliassos and Hassapis (1997) regarding non-expected utility specifications imply that various departures from expected utility are unlikely to explain the estimates, since they enhance precautionary wealth accumulation. A reversal of the precautionary effect on stockholding occurs only under the extreme assumption of piecewise linear indifference curves, but this leads to deterioration in predictions along other dimensions.

${ }^{26}$ Recently, Attanasio et al. (1998) proposed an interesting approach to handling this problem, focusing on the related criterion of splitting a sample between stockholders and nonstockholders $\left(S_{t}>0\right)$.

${ }^{27}$ Wealth is defined either to include housing or to exclude it in case it is highly illiquid and cannot be borrowed against. Non-housing wealth refers to liquid wealth in the form of checking or savings accounts or government bonds.

${ }^{28}$ The sign of the relationship of the wealth-to-income ratio to the tightness of the borrowing constraint depends on whether a high- or a low-return state has been realized (states 1 and 3 versus 2 and 4, respectively). The reason for this was explained in Section 4.1.

${ }^{29} \mathrm{We}$ are grateful to Carol Bertaut for drawing our attention to these data.

${ }^{30}$ Specifically, the criterion classifies as constrained households that indicated that they were denied credit or received less credit than requested (and did not subsequently reapply or apply elsewhere and receive full amount) or did not apply because they thought that the application would be rejected.

${ }^{31}$ Figures 2 and 5, also suggest that the role of risk aversion in differentiating constrained asset holdings is smaller under tighter constraints. Although the use of a universal cutoff is less objectionable under tight constraints and limited heterogeneity of preferences, the appropriate cutoff is not numerical but model-dependent. Again, use of portfolio restrictions can eliminate the problem.

32 A recent example is Jappelli et al. (1998), who employ the Survey of Consumer Finances. A household is classified as constrained if it has been turned down for a loan or it has failed to get as much credit as desired in the past, or it has been dissuaded from applying for credit in the past.

${ }_{33}$ Meghir and Weber (1996) propose an ingenious test of first-order conditions for the different purpose of discriminating between intertemporal nonseparabilities and borrowing constraints. 